\title{
O Movimento Indígena no Baixo Tapajós: etnogênese, território, Estado e conflito
}

\section{The indigenous movement in the Lower Tapajós: ethnogenesis, territory, State and conflict}

Rodrigo Correa Peixoto - Pesquisador no Museu Paraense Emílio Goeldi; professor do Programa de Pós-Graduação em Ciências Sociais da UFPA. E-mail: rpeixoto@museu-goeldi.br

Karl Arenz - Professor de História na Universidade Federal do Pará; doutor em História Moderna e Contemporânea pela Université Paris 4-Sorbonne. E-mail: arenz@free.fr

Kércia Figueiredo - Doutoranda do Programa de Pós Graduação em Ciências Sociais da UFPA; mestre em Serviço Social pela UFPA. E-mail: kerciapris@gmail.com

\section{Resumo}

O movimento indígena, reivindicando identidade e território, iniciou-se em 1998, na Flona Tapajós, com uma comunidade declarando-se Munduruku. Logo outras comunidades nos rios Tapajós, Arapiúns e Maró se assumiram indígenas e o movimento cresceu, e não apenas em virtude dos direitos dos povos indígenas, respaldados por legislações internacionais e pela Constituição de 1988, em um quadro de insuficiência de serviços públicos para as comunidades caboclas. Concorre também o desejo de pertencer a um povo, a um lugar e a uma luta. A etnogênese que se verifica no Baixo Tapajós está em sintonia com processos de retomada de tradições por grupos étnicos, então considerados aculturados ou extintos, em vários lugares do Brasil e América Latina. No Baixo Tapajós se assenta uma questão política relevante, com os indígenas significando um obstáculo aos negócios.

\section{Palavras-chave}

Movimento indígena. Identidade. Território. Resistência. Conflito.

\begin{abstract}
The indigenous movement claiming identity and territory has begun in 1998, in the Flona Tapajós, with a community declaring itself Munduruku. Soon other communities in the Tapajós, Arapiúns and Maró rivers assumed the indigenous identity and the movement gained intensity. The movement grows not only because of the indigenous rights supported by international laws and the 1988 Brazilian Constitution, in a context of deficient public services to the caboclo communities. There is also the will of belonging to a people, a place and a struggle. The indigenous emergence in the Lower Tapajós has to do with similar recovering of ethnical traditions by groups then considered extinct or acculturated in several places of Brazil and Latin America. In the Lower Tapajós this set a relevant political question, with the indigenous people signifying an obstacle to the business and institutional interests.
\end{abstract}

\section{Keywords}

Indigenous movement. Identity. Territory. Resistance. Conflict. 


\section{O MOVIMENTO EM LINHAS GERAIS}

No Baixo Tapajós, a emergência de identidades indígenas em comunidades caboclas é um estimulante fenômeno político. Numa área historicamente afetada por processos de extermínio e aculturação, autodenominados indígenas assumem atitude combativa à exploração econômica que gera desmatamento e conquistam relevância como agentes dos seus próprios objetivos, entre os quais o de assegurar os seus territórios. Agindo com essa disposição política no contexto conflituoso do Baixo Tapajós, os indígenas estabelecem um obstáculo ao avanço da fronteira e influenciam aquela realidade, provocando reações de agentes econômicos e governamentais. Esse é o quadro geral que o artigo propõe analisar.

Os indígenas do Baixo Tapajós avocam para si a descendência de povos de várias denominações ${ }^{1}$, o direito da autoidentificação e o atributo de resistentes. Eles celebram um renascimento depois do massacre levado a cabo sobre o tapuio, o índio tribal convertido em índio genérico (MOREIRA NETO, 1988), então visto pela elite branca como "sinônimo de cabano" (CÁRDENAS, 2008, p. 92). A cabanagem é celebrada como um exemplo de resistência na população que se autoidentifica como indígena, e as lideranças do movimento organizam eventos, como ocorreu na histórica comunidade de Cuipiranga (07-09/01/2011), onde, na comemoração dos 175 anos da Cabanagem, realçou-se o ideal de resistência dos tapuios e cabanos. O movimento indígena faz da Cabanagem uma história do presente.

Com essa disposição, comunidades então classificadas como caboclas passam a reclamar o reconhecimento legal como indígenas, assim como os correspondentes direitos étnicos. O silêncio historicamente imposto cede lugar à luta por visibilidade e território. Manifestações de indianidade ocorrem em encontros e eventos onde se valorizam adereços simbólicos, rituais diferenciadores e o poder do cacique. A história que nega a existência do indígena misturado porque só o reconhece como primitivo e puro é reinterpretada como uma longa experiência de assimilação imposta, contra a qual os indígenas resistiram até os dias de hoje, com sua histórica, silenciosa e cultural presença.

A indianidade ostentada pelas comunidades mestiças do Baixo Tapajós é referenciada em valores que têm a ver com continuidades históricas, inclusive territoriais, e não tanto com heranças biológicas. Ainda que a imigração nordestina atraída pela economia da borracha tenha deixado traços na população, salta aos

\footnotetext{
Conforme relação preparada pelo Conselho Indígena Tapajós Arapiúns (CITA), no Baixo Tapajós, hoje, os povos indígenas são os Munduruku, Apiaká, Tupinambá, Maytapu, CaraPreta Munduruku, Borari, Arapium, Tupaiú, Kumaruara, Arara Vermelha, Tapajó e Jaraki.
} 
olhos o caráter indígena da maioria, o inegável fenótipo dos habitantes das beiras dos rios Tapajós, Arapiuns e Maró. Não que isso seja um atributo necessário para a afirmação da indianidade, definida no plano das construções sociais e dos laços históricos e culturais. Mas a evidência física ajuda a sustentar escolhas identitárias e nutrir o movimento, na medida em que um caboclo diz "sou índio mesmo, como vou negar essa minha cara".

O movimento cresce não apenas em virtude da possibilidade de se obter direitos devidos aos povos indígenas, respaldados por legislações internacionais e pela Constituição de 1988, em um quadro de insuficiência de serviços públicos para as comunidades caboclas, desde sempre desprezadas. O indígena, antes envergonhado, sente-se orgulhoso de pertencer a um povo e a um movimento que busca afirmar identidades, direitos e territórios. E isso é contagiante.

O movimento indígena está na Resex Tapajós-Arapiúns, na Flona Tapajós, no PAE Lago Grande, na Gleba Nova Olinda e no Planalto Santareno, e cresce como uma cheia grande, conforme a expressão otimista de uma indígena. De fato, se em 1998 eram 20, hoje 48 aldeias se fazem representar com caciques e conselheiros em encontros regionais de um calendário histórico-político que inclui, além da Cabanagem, a Semana dos Povos Indígenas e a própria disputa pela fundação de Santarém - uma cidade - muito antes de 1661, data oficial de sua fundação, já que o Frei Gaspar de Carvajal relata que em 1542 os índios se encontravam ali em grande número e bem organizados, argumentam os estudantes indígenas na universidade.

Contudo, para bem avaliar a questão, é importante observar que o consenso não é generalizado nestas 48 comunidades/aldeias, em algumas se verificando mesmo uma acirrada polêmica entre parentes que divergem quanto à identidade indígena. São várias as razões dessa polêmica, que atravessa as comunidades e anuncia dificuldades para a expansão do movimento, podendo até fazer refluir a "cheia grande" que caracterizou o seu início. Pessoas com posições divergentes no movimento afirmam que as polêmicas são devidas à falta de poder agregador das lideranças que o impulsionaram inicialmente. Outros dizem que é grande a influência de agentes governamentais na produção de dissensões nas comunidades. De fato, é clara a reação de instituições estatais que fazem objeções ao movimento indígena em unidades de conservação e contestam pretensões territoriais em áreas que o ordenamento territorial na região reserva a outras finalidades.

Atritos entre parentes, entre e no interior das comunidades da Resex Tapajós-Arapiúns e de outras Unidades de Conservação, têm sido coisa comum. Tratando-se de uma escolha, a identidade pode ser assumida ou não. Interferem nesses subjetivismos que redundam em conflitos familiares e comunitários tanto 
filiações religiosas - católicos, com sua cultura sincrética versus pentecostais; estes em geral refratários às crenças indígenas - como a influência da mídia, da política partidária, de ONGs, de sindicatos e de agentes do poder público. Preconceitos sobre o índio são alimentados por esses agentes e influenciam o senso comum.

Desde quando se iniciou, em 1998, na comunidade de Takuara, um movimento pelo reconhecimento da condição indígena. O movimento cresceu, hoje com a adesão de 48 aldeias, termo que afirma o sentido político de grupos de parentes unidos por afinidades e chefiados por caciques. Etnogênese, ressurgência, emergência, reaparecimento e renascença, qualquer que seja o nome utilizado, o fenômeno gera sobressaltos em empresas e instituições. O IBAMA se contrapõe, uma vez que as terras indígenas reivindicadas sobrepõem-se à área da Flona, espaço projetado para abrigar atividades de exploração florestal. O Iterpa manifesta "impugnação" ao despacho da presidência da FUNAI (7/10/2011), que acolheu o relatório de identificação e delimitação da Terra Indígena Maró, situada na Gleba Nova Olinda I, justo em área destinada aos "permutados" fazendeiros transferidos do projeto Trairão, em São Félix do Xingu -, alegando "consequências desastrosas [...] não apenas aos investimentos idôneos, como à própria credibilidade da titulação oficial conferida por este Estado" (GOVERNO DO ESTADO DO PARÁ, 2012).

Os povos indígenas do Baixo Tapajós, que 14 anos atrás eram tidos como extintos, saíram da invisibilidade e se insurgem contra os amorfos rótulos de caboclos ou populações tradicionais. $\mathrm{E}$ assim passam a ser vistos pelos vários interesses estabelecidos na região como inconvenientes, impertinentes caboclos dizendo-se índios. Anuncia-se o agravamento dos conflitos e o poder do Estado mostra-se presente, relativizando direitos e contestando a institucionalização de novas terras indígenas (PEIXOTO, 2011).

\section{Etnogêneses}

O que ocorre na região de Santarém corresponde a uma tendência que engloba muitas outras emergências étnicas em várias partes do mundo. Peculiar em muitas das suas faces, mas longe de ser inusitada, a etnogênese que se verifica no Baixo Tapajós está em sintonia com processos de retomada de tradições por grupos étnicos, então considerados aculturados ou extintos, em todo o Brasil e América Latina. Miguel Bartolomé pontua, nas últimas décadas, vários casos desse surto de etnogêneses latinoamericanas - assim no plural, dada a variedade de circunstâncias -, afirmando tratar-se "da dinamização e da atualização de 
antigas filiações étnicas às quais seus portadores tinham sido induzidos ou obrigados a renunciar" (BARTOLOMÉ, 2006, p. 45).

$\mathrm{Na}$ Amazônia brasileira, entre outras emergências étnicas, verificamse processos no Médio Solimões, no Baixo Rio Negro, no Rio Juruá e na Volta Grande do Xingu - onde os Juruna têm a "identidade a todo momento posta à prova, tanto pelos técnicos da Eletronorte, quanto por indigenistas e missionários" (SARAIVA, 2007, p. 32). ${ }^{2}$ Importante notar que indígenas têm se feito visíveis também nas cidades, como é o caso de Campo Grande (MS), onde "orgulham-se de ter erguido 'a primeira aldeia urbana do Brasil"' (VAZ, 2010, p. 7). Da vergonha de ser ao orgulho de assumir-se, ocorreu dos anos de 1970 para cá uma drástica guinada, a qual Eduardo Viveiros de Castro dá a sua impressão:

Antigamente, muitos coletivos indígenas sentiam vergonha de sê-lo, e o governo tinha todo interesse em aproveitar essa vergonha inculcada sistemicamente, tirando as conseqüências jurídico-políticas, digamos assim, do eclipsamento histórico da face indígena de várias comunidades 'camponesas' do país. Agora, ao contrário, 'todo mundo quer ser índio' dizemos, entre intrigados e orgulhosos (CASTRO, 2006, p. 43).

Não obstante a pluralidade de circunstâncias, que para a preocupação dos patrocinadores do progresso têm transformado apáticas comunidades nativas em ativas coletividades políticas, a reivindicar identidade e território e subverter a indistinção forçada, esses vários processos encerram denominadores comuns, entre os quais estão as novas legislações garantidoras de direitos, que comparecem como respaldo fundamental desse fenômeno global. Importante que foram para conferir direitos antes negados (BARTOLOMÉ, 2006), as novas legislações não vieram, contudo, como um maná caído dos céus. Antes disso, elas são resultado de mobilizações políticas.

No caso brasileiro, Viveiros de Castro (2006) conta que a ditadura militar, na sua geopolítica modernizadora, pretendeu "enfiar goela abaixo o seu famoso projeto de emancipação” (CASTRO, 2006, p. 41), cujo escopo era criar "um instrumento jurídico para discriminar quem era índio de quem não era índio" (CASTRO, 2006, p. 41). Contra essa pretendida "desindianização", várias organizações indígenas se formaram por uma luta conceitual. A condição indígena não podia ser vista como um estado transitório na direção inevitável do “branqueamento". "A idéia é a de que os índios 'ainda' não tinham sido vencidos, nem jamais o seriam” (CASTRO, 2006, p. 42, grifo do autor).

Conforme observa o antropólogo Louis Forline (University of Nevada, Reno), ali, essa contestação por parte da Eletronorte e a necessidade de os indígenas lutarem pela afirmação da identidade ocorrem "apesar de os Juruna terem uma área já demarcada e homologada desde os anos 1980". 
O entendimento de que o importante é assumir coletivamente a identidade indígena, e não o fato de ser "índio puro", em evidente contraste cultural com a sociedade envolvente, passou a permear as leis, permitindo o reconhecimento de populações mestiças que se autoidentificam como indígenas. Nesse sentido, as legislações que presentemente respaldam as emergências indígenas são produtos de uma construção social que ultrapassou velhos conceitos. A mestiçagem não impede que as comunidades se reconheçam e sejam reconhecidas como indígenas. Desconstruiu-se, assim, a ideia excludente do índio como aquele ser tradicional, nu, morando no mato.

Marcos dessa desconstrução são as discussões conceituais levadas a efeito por João Pacheco de Oliveira (1999) que, entre outros autores, trata da etnicidade de "populações tidas como de pouca distintividade cultural (ou seja, culturalmente 'misturadas')" (OLIVEIRA, 1999, p. 12). Não obstante serem longamente abandonados como objeto de estudos etnológicos e de ações indigenistas, uma vez tidos como irremediavelmente aculturados e, portanto, sem perspectivas como sujeitos históricos, os povos indígenas do Nordeste brasileiro ressurgiram como foco de atenção "a partir de fatos de natureza política - demandas quanto à terra e assistência formuladas ao órgão indigenista” (OLIVEIRA, 1999, p. 16). Demandando a demarcação de terras, os índios do Nordeste, "desprovidos de forte contrastividade cultural” (OLIVEIRA, 1999, p. 17), instalam um "processo de etnogênese, abrangendo tanto a emergência de novas identidades como a reinvenção de etnias já estabelecidas” (OLIVEIRA, 1999, p. 18).

Percebidas como processos políticos, as etnogêneses vinculam-se a situações regionais específicas - na Amazônia, assumindo "uma importante dimensão ambiental e geopolítica”, conforme Oliveira (1999, p. 18). Em vários países latino-americanos elas ocorrem em contextos culturais e institucionais que, se antes adversos, hoje favorecem a "desestigmatização da filiação nativa" (BARTOLOMÉ, 2006, p. 45). Uma perspicaz interpretação política desses processos é dada por Miguel Bartolomé, para quem, na América Latina, as várias etnogêneses correspondem às lutas das populações nativas no sentido de "se constituírem como coletividades, como sujeitos coletivos, para poderem se articular ou se confrontar com seus Estados em melhores condições políticas" (BARTOLOMÉ, 2006, p. 44, grifo do original).

O forte impulso inicial desse processo no Baixo Tapajós, com o movimento conquistando adesões em dezenas de comunidades caboclas, prometia uma presença indígena importante, mais ainda da que se verifica atualmente com o reconhecimento formal da Terra Indígena Maró e a possibilidade da Terra Indígena Cobra Grande, no PAE Lago Grande. Contudo, na Resex Tapajós- 
Arapiuns, as polêmicas no interior das comunidades, e na Gleba Nova Olinda, a oferta de empregos pelas empresas madeireiras, no quadro das reações contrárias ao movimento, produziram certo refluxo naquele ímpeto que uma indígena comparou a uma cheia grande. De todo modo, assentou-se na região uma questão política relevante - o fenômeno se enquadrando na antevisão proposta por Bartolomé, para quem "os Povos Originários não são apenas o passado e o presente da América Latina, mas também parte constitutiva de seu futuro" (BARTOLOMÉ, 2006, p. 52).

A mobilização por identidade e direitos - inclusive de território - é sustentada por valores coletivos. Valores diversos do individualismo que prevalece na sociedade. Ela também se caracteriza pela atitude combativa de caboclos convertidos em indígenas no contexto de comunidades desvalidas, na relação com o Estado. Nesse quadro de abandono, a identificação étnica tem a ver com estratégia de obtenção de vantagens garantidas por direitos. Se antes os coletivos indígenas sentiam vergonha de sê-lo, como afirma Castro (2006); ou receio de assumir uma identidade estigmatizada em ambientes adversos, como considera Cardoso de Oliveira (1976), referindo-se aos Terêna de Mato Grosso, hoje a conjuntura mudou - e ser indígena é uma escolha estratégica, em se tratando de sobrevivência social: "se a identidade étnica é um valor, enquanto categoria ideologicamente valorizada, ela é passível de uma certa escolha ou opção em situações determinadas" (CARDOSO DE OLIVEIRA, 1976, p. 22).

Educação e saúde indígenas em padrão superior aos tacanhos serviços regulares, acesso à universidade, utilização autônoma dos recursos naturais em territórios demarcados - evidentemente as comunidades são movidas por esses direitos - mas não apenas. As motivações subjetivas e coletivas que dão impulso à identificação étnica não podem ser reduzidas a um mero instrumentalismo voltado à obtenção de direitos negados ao caboclo. A escolha da identidade indígena não corresponde apenas a uma atitude utilitária, visando direitos diferenciados. Concorre igualmente o desejo de pertencer a um povo, a um lugar e a uma luta.

De acordo com Bartolomé, concorre para a assunção subjetiva da identidade e para os processos coletivos de etnogênese, o intuito de pertencer a uma coletividade étnica. A valorização de "um pertencimento social carregado de conteúdos afetivos” (BARTOLOMÉ, 2006, p. 56); a atitude de preferir “a intensidade das relações intraétnicas e parentais, em oposição ao individualismo competitivo da sociedade estatal" (BARTOLOMÉ, 2006, p. 56); "o sentido de solidariedade" e os "valores emocionais", próprios das relações comunitárias, em vez das relações sociais baseadas em "interesses motivados por juízos racionais" (WEBER, 2002, p. 71): todos esses valores fazem atraente a alternativa 
de pertencer a um movimento que propõe o futuro como uma volta aos seus. Assim, o retorno às antepassadas etnias é uma viagem de volta motivada por valores existenciais garantidos por direitos.

No Baixo Tapajós, a dimensão política dos processos de etnogênese relaciona-se principalmente com a apropriação de território pelos grupos étnicos. "Índio sem terra é ninguém", sintetiza um indígena, na sua argumentação de que a soberania passa necessariamente por território. As autoproclamadas aldeias indígenas não estão voltadas para o passado, mas preocupadas em recuperar formas tradicionais de viver. Elas estão sim empenhadas em se "projetar no futuro sem abrir mão dos seus valores e da sua cultura” (LEROY, 2010, p. 105). E esse projeto de futuro inclui necessariamente uma territorialidade própria, eminentemente política e contestatória de outras lógicas territoriais que esvaziam a identidade indígena de sujeitos coletivos de direitos.

Contudo, em termos territoriais, não se trata tanto de uma viagem de volta, conforme a metáfora consagrada por João Pacheco de Oliveira ${ }^{3}$, já que eles, os indígenas, por um longo tempo classificados como caboclos, sempre estiveram lá. E nas beiras do Tapajós e do Arapiúns, continuaram as tradições indígenas, as comunidades se fundando em relações de parentesco e vizinhança, justapondo o nativo modo de vida a culturas introduzidas. O fato novo nas comunidades foi o estabelecimento de vínculos políticos com entidades indígenas e organizações aliadas, que mobilizaram a etnogênese e demandaram da FUNAI a correspondente requalificação dos territórios.

\section{Direitos como motivação}

Os povos indígenas são figuras jurídicas com lastro na Constituição Federal de 1988 e na Convenção 169 da Organização Internacional do Trabalho devidamente reconhecida pelo Estado brasileiro depois de 10 anos de polêmicas, enquanto minorias étnicas são sujeitos coletivos de direitos, inclusive o direito à autodeterminação; condição que dá aos coletivos indígenas o direito de se definirem como tal.

Marco decisivo dos respaldos legais às emergências indígenas no Brasil é a Constituição, que inverteu o projeto de emancipação (CASTRO, 2006), levado a

\footnotetext{
3 A partir da poesia "Todo o dia é dia D", de Torquato Neto, cujos versos aludidos são: "desde que saí de casa, trouxe a viagem de volta gravada na minha mão, enterrada no umbigo, dentro e fora assim comigo, minha própria condução".
}

Novos Cadernos NAEA • v. 15 n. 2 • p. 279-313 • dez. 2012 
efeito pelo governo durante a ditadura militar, com o intuito de fazer submergir os indígenas na sociedade nacional, liberando-os da sua condição étnica. ${ }^{4} \mathrm{~A}$ Constituição valorizou a identidade indígena não como atributo ontológico individual, mas como movimento coletivo, fazendo com que as comunidades indígenas se tornassem sujeitos coletivos de direitos (CASTRO, 2006, p. 43). Como tais, os indígenas passam a reivindicar do Estado saúde, educação, aposentadoria, espaço na universidade e, naturalmente, território, na forma de direitos étnicos e programas de ações afirmativas. "Nossa identidade é esse espírito de luta", diz uma universitária, afirmação que coincide com a de que “indianidade é um 'estado de espírito” (CASTRO, 2006, p. 42).

$\mathrm{Na}$ luta por identidade e território, os movimentos indígenas estabelecem com as sociedades nacionais e suas instituições relações conflituosas no plano da política, dos discursos e das alternativas legais, processos esses que geram novos instrumentos e categorias para o prosseguimento da luta. No caso do Brasil, a expressão populações tradicionais, por exemplo, vigente nos meios ambientalistas desde os anos 1980, conforme explica Florêncio Vaz (2010), e estabelecido oficialmente 20 anos depois, pela Lei do Sistema Nacional de Unidades de Conservação (SNUC), abrigou pescadores, quilombolas, caboclos, ribeirinhos e indígenas em áreas de conservação, particularmente na Flona Tapajós ${ }^{5}$, de onde, a princípio, por força da legislação, eles deveriam sair. "A nova legislação já permitia populações tradicionais dentro das Flonas, com alguma liberdade para desenvolverem suas atividades econômicas" (VAZ, 2010, p. 27).

4 Louis Forline (University of Nevada, Reno), em leitura de versão preliminar desse artigo, sugere "mencionar que o conceito da 'emancipação' remete aos tempos pombalinos que, por sua vez, abraçou essa ideia para 'libertar' os índios, situação que na realidade os fragilizou, pois removeu a proteção paternalista dos jesuítas e os submeteu ao processo de assimilação forçada".

5 O surgimento do termo populações tradicionais na luta pela permanência das comunidades na Flona Tapajós é historiado como se segue por Edviges Ioris (2005, p. 284). "The eighteen communities' long history of occupancy in the region was directly threatened by the creation and implementation of the Flona Tapajós on account of National Forest legislation that did not allow permanent residents in the reserve. Thus, when the implementation of Flona Tapajós was initiated, federal government agencies responsible for the implementation of Flonas (National Forests) started to undertake procedures to dispossess the local communities from their lands. Claiming land rights, most people did not accept displacement, and they strongly resisted, which resulted in an endless quarrel between them and the Flona Tapajós administration. [...] After some years of discussion, this change was put into legislation in 2000, when the National Congress approved the new version of the law that governs environmental reserves in Brazil (SNUC, 2000). According to this new version, National Forests accepted the presence of communities recognized as "traditional people." Therefore, as "traditional people," the communities in the Flona Tapajós acquired legal recognition of their rights to remain in their lands twenty six years after the reserve's creation, and their areas of occupation were incorporated into the reserve's management plan. 
Portanto, o termo populações tradicionais, ainda que genérico e ambíguo, implicando uma classificação evolutiva (VAZ, 2010), que pode ser entendida de forma pejorativa, serviu, naquele momento, para acomodar os moradores da Flona e de outras Unidades de Uso Sustentável no bojo da lei que instituiu o SNUC. No entanto, os que hoje se assumem indígenas nessas Unidades de Uso Sustentável não querem continuar a ser classificados como populações tradicionais - atribuição genérica dada por terceiros, sem a subjetividade e os valores culturais que caracterizam "uma identidade própria em si" (ARENZ, 2003, p. 100).

Esse sentimento de identidade própria apareceu com nitidez por ocasião da I Semana dos Povos Indígenas - evento realizado na Universidade Federal do Oeste do Pará (11-17/4/2011) - no diálogo estabelecido entre a jovem Lucy, que se descobriu indígena quando foi morar fora da região, e dona Catarina, uma senhora autodenominada indígena moradora na Resex:

- "Ser indígena é ser o que nós somos, o que nós vivenciamos dos nossos antepassados. Porque muita gente vive sem saber quem é. Nós compreendemos nossas raízes". Ao que dona Catarina emendou: - "Não é só compreender, mas é também dar valor. Nós damos valor àquilo que é nosso. Nós damos valor à nossa cultura."

Entre as legislações, importância capital tem a Convenção 169 da OIT sobre Povos Indígenas e Tribais, adotada em Genebra, em 27/06/1989. Vale notar que a Convenção não obriga os países a adotarem suas resoluções; e a forma pela qual ela é adotada difere de país para país. Assim, após mais de uma década de intensos debates, os quais em grande medida giraram em torno do conceito "povos", o Brasil a ratificou, por meio do Decreto Legislativo no 143, de 20/06/2002. A Convenção 169 se aplica no Brasil aos povos indígenas e quilombolas, reconhecidos como minorias étnicas pela Constituição Federal de 1988, e conceitualmente exclui a dimensão política de autodeterminação dos povos, dizendo respeito tão somente a comunidades históricas.

Extremamente importante na Convenção é o seu Artigo $1^{\circ}$, cuja redação estabelece que "A consciência de sua identidade indígena ou tribal deverá ser considerada como critério fundamental para determinar os grupos aos que se aplicam as disposições da presente Convenção". Significa dizer que os indígenas têm direito à autoidentificação. Essa prerrogativa, respaldada na

\footnotetext{
${ }^{6}$ "O critério da auto-idenficação, considerado como essencial para a caracterização de um grupo social diferenciado, surge a partir de lições de Frederick Barth (1969), que inovou os métodos para constituição de limites de unidades étnicas, procurando-se fugir aos fundamentos biológicos, linguísticos e raciais (O’DWYER, 2002, p. 14).
} 
"história centenária dos primeiros habitantes indígenas que vieram fazer parte da colonização do baixo Tapajós" (FUNAI, 2009), está na base da revitalização da condição étnica que se verifica na região.

\section{Frente ao movimento indígena, a atuação do Estado na região}

Quando comparece mediante mecanismos legais e administrativos, o Estado normatiza um planejamento capaz de integrar a Amazônia ao mercado nacional e internacional, inclusive possibilitando a transferência de vastas extensões de terras a grupos empresariais (LOUREIRO, 2004). E quando ignora a heterogeneidade de territórios (ALMEIDA, 1995), o Estado visa à supressão de alternativas de uso e à homogeneização da região, oficialmente vocacionada para a produção de grãos, minérios, energia, carne e madeira. É o velho autoritário olhar que vê a região vazia humana e culturalmente, importando apenas o volume de dólares a ser gerado por exportações. Segundo Vainer (1993), essa perspectiva encerra o objetivo de conquista, de anulação do outro e da apropriação de território para a finalidade de exploração econômica de recursos naturais e os indígenas aparecendo como empecilho à marcha do progresso, portanto, um obstáculo a ser removido.

Para empresas e instituições é menos complicado lidar com caboclos ou com populações tradicionais do que com indígenas, cheios de espírito de luta e plenos de direitos. Os caboclos enquadrados no rótulo populações tradicionais são mais facilmente manejados. Pode-se conceder a eles a permanência nos espaços de exploração capitalista da natureza como "sujeitos biologizados, isto é, como uma mera extensão dos recursos naturais, sem consciência e direitos" (ALMEIDA, 2010, p. 384). E, conforme as circunstâncias, pode-se simplesmente removê-los para abrir espaço à produção. Pierre Leroy conta que no "planalto santareno, no município de Santarém, no Pará, ao longo de mais de 100 anos, formou-se um campesinato composto na sua origem de remanescentes da borracha. Em meia década, o eldorado da soja os varreu do mapa" (LEROY, 2010, p. 96). Os indígenas, ao contrário, significam um obstáculo aos negócios e aos interesses institucionais.

A FUNAI reconhece o contexto desfavorável. Nas palavras de uma representante da Fundação, na mesa de abertura do I Semana dos Povos Indígenas (11-17/04/2011), “a FUNAI está empenhada no reconhecimento dos territórios dos povos indígenas na região, enfrentando conflitos com outras instituições que vêm na contramão desse processo". De fato, no que diz respeito às reivindicações de reconhecimento legal da condição indígena feitas pelas 
aldeias situadas na área da Flona Tapajós, a FUNAI se mobilizou no sentido de reconhecer os Munduruku tanto da aldeia Takuara, onde eclodiu o movimento indígena em 1998, como nas aldeias Bragança e Marituba, que logo a seguir também reivindicaram descendência indígena.

Contudo, já em 2006, o Conselho Indígena Tapajós-Arapiúns (CITA) recebeu comunicação da FUNAI que informava que o Projeto de Proteção às Populações e Terras Indígenas da Amazônia Legal (PPTAL) não mais incluía nos seus planos a demarcação de terras indígenas no Tapajós e no Arapiúns. A justificar essa decisão, duas razões: a falta de tempo para concluir essas atividades antes do encerramento do próprio PPTAL, e as aparentes inconsistências na lista dos grupos indígenas preparada pelo CITA (CÁRDENAS, 2008, p. 41). Segundo Omaira Cárdenas, os antropólogos da FUNAI teriam dúvidas quanto à descendência indígena dos membros do CITA (CÁRDENAS, 2008, p. 41).

Se por um lado o papel da FUNAI, conforme a Constituição de 1988, é zelar pelo reconhecimento dos direitos dos povos indígenas por parte da sociedade, por outro, seus dirigentes precisam se ajustar às injunções do Estado, que, aliás, recentemente cortou substancial volume de recursos da Fundação. A mídia (Folha de S. Paulo, Fernanda Odilla, 28/01/2011) noticia que o aval dado para Belo Monte teve a oposição de técnicos da própria FUNAI. A avaliação dos técnicos que se colocaram contra a licença de instalação não foi levada em conta pelo órgão, porque acima da integridade das comunidades indígenas na região está um projeto nacional para a Amazônia.

Além de hidrelétricas, o progresso hoje expresso no gasto termo “desenvolvimento sustentável”, compreende mineração, siderurgia, pastagens e campos de cultivo. Institucionalizar territórios indígenas representa obstaculizar a mineração e o agronegócio, num momento em que os preços das commodities agrícolas e minerais se elevam (ALMEIDA, 2010, p. 382). Por isso, ao contrário de patrocinar a causa indígena, o Estado opta por favorecer o desenvolvimento das atividades econômicas. Nas instituições nacionais ocorre o que Alfredo Wagner chama de uma "campanha de desterritorialização", que "busca flexibilizar as normas que asseguram os direitos territoriais [...] etnicamente configurados" (ALMEIDA, 2010, p. 385). Não é à toa que “o Estatuto do Índio permanece sem aprovação legislativa e há movimentação parlamentar no sentido de abrir as terras indígenas à extração mineral" (ALMEIDA, 2010, p. 384).

No Baixo Tapajós, a crescente mobilização indígena começa a interferir numa organização do espaço que busca acomodar vários interesses. O arranjo espacial na região inclui as várias modalidades previstas pelo Sistema Nacional de Unidades de Conservação (SNUC) e, prioritariamente, os interesses econômicos, 
dados pelas hidrelétricas, a mineração, a pecuária, a agricultura de exportação e a exploração madeireira. Nesse contexto, os direitos indígenas são secundários. As atuais contestações de agências estatais em processos de demarcação de terras indígenas, todo o atropelo de procedimentos na liberação da licença prévia para Belo Monte e as propostas de "flexibilizar" direitos indígenas, revelam as opções do poder.

\section{As medidas governamentais para garantir a vocação madeireira da região}

Em 2006, o então governador do estado do Pará autorizou, através do Decreto $n^{\circ} 2.472 / 2006$, assentamento na Gleba Nova Olinda. O assentamento é destinado aos "permutados" - fazendeiros do sul do país que adquiriram títulos fundiários do governo do Pará na década de 1980, com o incentivo oferecido pelo Iterpa, no âmbito do projeto Trairão, no município de São Félix do Xingu, então forçados a se retirar de lá. ${ }^{7}$ Esse foi o estopim para uma série de conflitos que se instalou na região.

As permutas trouxeram em seu bojo a ocorrência de crime de pistolagem, ameaças às lideranças locais, retirada ilegal de madeira, alteração nos costumes locais, caça altamente predatória, que está sendo exercida pelos funcionários dos 'permuteiros' que trabalham na extração de madeira, e uma certeza de que ocorrerá o desmatamento futuro destas áreas (STTR; CPT, 2008, p.26).

Essa medida se deu no contexto de uma acelerada ocupação no conjunto de glebas Mamurú-Arapiuns, a partir de 2000, visando à exploração madeireira; processo esse assistido pelo governo, que se apoiava em dois instrumentos jurídicos: as ADIPs (Autorizações para Detenção de Imóveis Públicos) e a celebração de escrituras públicas de permuta. As ADIPs foram concessões estaduais de uso da terra, que formalizavam o direito à exploração dos recursos naturais, impedindo que a situação fundiária fosse um empecilho para a atividade madeireira, desconsiderando a ocupação tradicional da área e a fragilidade ambiental. As escrituras de permuta garantiram juridicamente o assentamento dos permutados em terras de usos de populações tradicionais. O documento de escritura de permuta concedido pelo governo atribuiu aos permutados a tarefa

Uma vez que a Funai determinou, em 1990, por meio do Decreto no 98.865/1990, que essas terras secularmente ocupadas pelos índios Kayapó, constituíam área imemorial indígena, determinou-se a retirada dos ocupantes exógenos. Forçados a sair, os fazendeiros exigiram do governo do Estado a indenização dos valores pagos para a aquisição daquelas terras ou uma área de permuta como compensação. Para eles foi destinada parte da gleba Nova Olinda, ocupada por dezenas de comunidades. 
e realizar a autodemarcação e o georeferenciamento de suas terras e das terras vizinhas das populações tradicionais. ${ }^{8}$ Os conflitos se acentuaram, então. ${ }^{9}$

A fim de amenizar a situação, o governo seguinte, do Partido dos Trabalhadores, consolidou, no conjunto de glebas Mamurú-Arapiuns, através do Decreto $n^{\circ}$ 1.149/2008, a Área de Limitação Administrativa Provisória (ALAP). O documento impedia, no seu Art. $2^{\circ}$, as atividades e empreendimentos efetiva ou potencialmente causadores de degradação ambiental, assim como vetava atividades relacionadas ao corte raso da floresta e da vegetação nativa. O documento que instituiu a ALAP proibiu também atividades relacionadas ao uso direto dos recursos naturais, exceto aquelas ligadas a atividades sustentáveis, historicamente realizadas por comunidades tradicionais.

Por outro lado, a promulgação da lei federal de gestão de florestas públicas permitia ao governo a regularização da exploração madeireira através de procedimentos de concessão florestal. Porém, antes da formalização das concessões, a lei obrigava que as florestas públicas ocupadas ou utilizadas por comunidades locais fossem identificadas para a destinação, seja através de criação de Reservas Extrativistas e/ou de desenvolvimento sustentável, bem como por transferência de uso, seja por meio de assentamento florestal, assentamento de desenvolvimento sustentável, agroextrativistas ou similares. A promulgação dessa lei significou a viabilização do processo de ordenamento fundiário no conjunto de glebas Mamurú-Arapiuns, que possibilitou às comunidades locais influir na definição daquele espaço, inclusive por meio de cartografias e autodemarcações. Para os indígenas, possuir uma representação cartográfica de si mesmos mostrou-se fundamental para garantir direitos territoriais (ação coletiva descrita mais a frente), fato posteriormente reconhecido no Relatório de Identificação e

8 Dessa forma, o governo se livrou da sua obrigação de mapear e delimitar, concedendo aos principais interessados uma função que deveria ser sua. Esse fato fez com que as comunidades se sentissem indignadas, aguçando ainda mais o conflito na região. $\mathrm{Na}$ aldeia de Novo Lugar, os comunitários relatam que os madeireiros chegaram dotados de GPS e foram invadindo o território sem pedir autorização. Foram marcando e demarcando sem dar explicações, como se a terra fosse deles. E assim se apropriaram de área do final da TI Maró, onde é grande a incidência da árvore Mururé, da qual os indígenas extraem uma seiva medicinal. Os indígenas, por sua vez, como já relatado acima, autodemarcaram a sua terra, colocando-a no mapa, com essa fração de terra incluída. Reivindicam uma área de 42 mil hectares. No limite dela estão os permutados, que demandam 15 mil hectares dentro da TI Maró. Essa é a disputa que instiga o principal conflito territorial da região.

9 De acordo com relatório produzido pelo Ideflor, na Gleba Nova Olinda os conflitos iniciamse "a partir da chegada dos grileiros e madeireiros no início de 2000", e são motivados pela extração irregular de madeira (IDEFLOR, 2009, p. 58). Ainda segundo o relatório, "nas comunidades indígenas que fazem fronteira com as comunidades ribeirinhas, os conflitos são acirrados por grileiros" (IDEFLOR, 2009, p. 58).

Novos Cadernos NAEA • v. 15 n. 2 • p. 279-313 • dez. 2012 
Delimitação da TI Maró elaborado pela antropóloga Georgia da Silva, e aprovado pela FUNAI em 7 de outubro de 2011 (FUNAI, 2011).

No entanto, Fisher (2010) faz uma avaliação da regularização fundiária, no ponto em que a medida governamental titula lotes individualmente, inserindo-os no mercado de terras:

A regularização fundiária dos territórios tradicionalmente ocupados pode ser vista como um mecanismo de dupla eficácia, uma vez que garante os direitos territoriais pleiteados por comunidades tradicionais, ao mesmo tempo em que, paralelamente, titula, estabiliza e insere no mercado novas terras, que são passíveis de serem incorporadas às frentes de acumulação do capital (FISHER, 2010, p.173).

\section{Reações e contestações}

Entre os que se autodenominam, ganha corpo um novo significado do que é ser indígena hoje, para além do estereótipo de corpos pintados e adornos de plumas, embora esses se façam presentes. O movimento somou adesões de comunidades e aumentou também a reação de quem se sentiu incomodado com a novidade. Moacir, um indígena assumido na Resex Tapajós-Arapiúns, percebe assim o momento: "Ser indígena é a gente se identificar como indígena, é querer. Ser indígena é ter muitos direitos, mas incomoda muito os outros".

Os interesses que o movimento indígena fere no Baixo Tapajós não são poucos. Reações vêm do próprio Estado, visto que IBAMA, ICMBio e até mesmo a UFOPA contestam a demarcação de terras indígenas na Flona Tapajós. Demais agências estatais envolvidas na gestão territorial do Baixo Tapajós não escondem o desgosto. Essa percepção de forças contrárias no governo é também de servidores da FUNAI: “Como a FUNAI é órgão de governo, muita gente, muitos órgãos do próprio governo interferem na FUNAI, contra as demarcações. Às vezes parece que as forças contrárias vão vencer". Por sua vez, a FUNAI relutava em instalar um PI em Santarém, reivindicado pelos indígenas que precisavam ir até Itaituba agenciar seus direitos. A inquietação invade instituições e empresas. Uma coisa simples é afastar do caminho o reles caboclo desprovido de associação política e direitos, outra bem diferente é conflitar com povos indígenas organizados num movimento e amparados na legislação internacional e na Constituição, como constatou uma estudante no mini-curso indígena que teve lugar na I Semana dos Povos Indígenas, realizada na UFOPA (11-17/04/2011).

A expansão econômica na fronteira, particularmente a exploração madeireira na Gleba Nova Olinda, encontra um obstáculo. Minorias étnicas 
plenas de direitos reivindicam território, contrariando um projeto nacional de ocupação e gestão territorial da Amazônia, que inclui Reservas Extrativistas e Florestas Nacionais, entre outras Unidades de Conservação, projetos de assentamento e áreas de concessão florestal, ordenados em zoneamentos ecológico-econômicos. É verdade que o extrativismo das chamadas populações tradicionais encontrou algum espaço no mosaico de interesses regionais, onde sobressaem a grande mineração, a exploração madeireira e o agronegócio. Mas os indígenas não querem a veste genérica de populações tradicionais, criadas e adequadas à funcionalidade desse projeto nacional, onde o Sistema Nacional de Unidades de Conservação (SNUC) comparece. Para os indígenas, o território significa a própria existência.

Contudo, entre o que os moradores da Resex Tapajós-Arapiúns, da Flona Tapajós, do PAE Lago Grande e da Gleba Nova Olinda afirmam que são e o ansiado território indígena, que permitirá a eles exercerem no cotidiano esse sentimento interno que define uma identidade própria (ARENZ, 203, p. 103), coloca-se a lei. "Índios são aqueles que 'representam a si próprios", diz Eduardo Viveiros de Castro (2006, p. 47). Mas, essa asserção e essa autorrepresentação não bastam para a comunidade cabocla que se reconhece indígena "deixar de sofrer a própria indianidade e passar a gozá-la” (CASTRO, 2006, p. 43) no seu próprio território. É a legislação, a Constituição de 1988 e os decretos e portarias que sistematizam os procedimentos de demarcação. É todo esse arcabouço jurídicolegal que pode arrogar ao indígena o direito fundamental do território.

Nesses termos, é, pois, o campo jurídico, informado por relatórios antropológicos e ações legais, que define a existência do indígena. E, conforme a letra da lei, no procedimento de demarcação, antes que o processo se conclua com a homologação da terra indígena, há a possibilidade de contestações, que podem questionar os relatórios antropológicos de identificação e delimitação e os despachos da presidência da FUNAI, que os acolhe. Foi justamente isso o que ocorreu no caso dos procedimentos para a demarcação da terra dos Munduruku, na Flona Tapajós. É iteressante, nesse caso, observar que a contestação veio do Estado - do IBAMA, do ICMBio e também da UFOPA, assim como ocorre com a Terra Indígena Maró, contestada pelo Instituto de Terras do Pará (ITERPA).

Ilustrativo do campo jurídico, como arena de conflitos, é o caso da TI Maró, cujas conclusões do Relatório Circunstanciado de Identificação e Delimitação, aprovadas pelo Despacho $\mathrm{n}^{\circ} 107$, de 7 de outubro de 2011, foram finalmente publicadas pela FUNAI. É importante notar, mediante intimação efetuada pelo Ministério Público Federal, a quem compete o controle externo da administração pública: 


\begin{abstract}
A Justiça Federal em Santarém deu prazo de 30 dias à FUNAI, sob pena de multa diária, para publicar o relatório de identificação da Terra Indígena Maró, localizado no rio Arapiuns, dentro da Gleba Nova Olinda, local de intensos conflitos entre indígenas, comunidades tradicionais e madeireiros (JORNAL O IMPACTO, n. 837, 10/6/2011).
\end{abstract}

À demora na publicação do relatório, seguiu-se a ação contestatória do Instituto de Terras do Pará (ITERPA) (GOVERNO DO ESTADO DO PARÁ, 2012), que se apressou na defesa dos "empreendimentos idôneos que trazem benefícios à região" e na crítica ao relatório, cujo conteúdo classificou como "simples divagações ideológicas". O fato é que a identificação e delimitação de novas áreas indígenas afetam o controle institucional de territórios, o mercado de terras e a expansão empresarial nessa fronteira, onde as glebas MamurúArapiuns reúnem a maior quantidade de áreas florestais não destinadas no estado, disputadas, portanto, por interesses diversos.

Aliás, é essa justaposição de interesses (LÉNA; OLIVEIRA, 1991), essa situação de conflito social (MARTINS, 1996) e essa ilegalidade e criminalidade social e ambiental (CASTRO, 2005) o que caracteriza a fronteira de expansão econômica. O conflito envolve diferentes agências estatais, que produzem interpretações diversas. Exemplo disso é a contenda que se refere ao intenso tráfego de balsas de madeira pelos rios Arapiuns e Tapajós: "O Procurador Federal declarou que havia indícios de extração irregular da madeira. A Secretaria de Meio Ambiente (SEMA) veio fiscalizar a origem das toras e disse que tudo era legal e dentro dos conformes" (MILANEZ, 2010).

Nesse contexto, o documento do ITERPA toma emprestado a declaração, segundo a qual 'tais ações indigenistas obedecem a uma agenda geopolítica externa, visando o engessamento de enormes áreas de produção e servindo de óbices à realização de obras estruturantes na região, a fim de mantê-la subpovoada e subdesenvolvida' (GOVERNO DO ESTADO DO PARÁ, 2012). O movimento indígena é visto como um estorvo ao chamado progresso, daí a reação dos que o promovem.

\title{
O movimento indígena no Baixo Tapajós
}

O movimento rememora a história centenária dos povos que habitavam densamente a região, quando Carvajal, percorrendo o Médio Amazonas, percebeu-a, no século XVII, como "uma única grande província" indígena "as duas faixas ribeirinhas estavam pontilhadas de aldeias, mas os maiores assentamentos estavam recuados umas duas léguas pelo interior e são definidos 
como 'grandes cidades"' (CUNHA, 1992). Isso antes dos aldeamentos misturarem as diversas etnias, introduzirem valores europeus e confundirem a organização social então existente. O movimento refere-se à resistência dos cabanos, quando o índio tribal convertido em tapuio, então visto como cabano, insurgiu-se contra a elite política e tomou o poder. E, como herdeiro dessa história, o movimento ganha forma quando o caboclo se posiciona, valendo-se do direito de se fazer ator com seus próprios objetivos frente aos outros, identificando-se como Arapiun e Borari, Jaraki e Munduruku, entre outras denominações recuperadas ou criadas.

O posicionamento do chamado caboclo dá sentido político a um movimento encaminhado coletivamente, é verdade, mas, pelo menos no seu início, fortemente puxado pela liderança do antropólogo Florêncio Vaz. Esse frade franciscano, que se identifica como indígena do povo Maytapu, então na gênese do movimento como agente da Comissão Pastoral da Terra (CPT) e hoje na condição que ele mesmo coloca de "pesquisador-nativo", conta que tudo começou após o falecimento do pajé Laurelino, cuja história real é alimentada como uma tradição fundante:

Ainda em fins de 1998 aconteceu um fato marcante na história regional: o pequeno vilarejo chamado Takuara, localizado à margem direita do rio Tapajós, município de Belterra, assumiu publicamente sua identidade indígena. A decisão foi tomada após o falecimento do seu líder, o curador Laurelino (31/05/1998), que provocou grande comoção entre as famílias, que se reuniram para escutar, repetidas vezes, a entrevista que ele me concedera, em 1994 e 1995. Causou profunda reflexão os trechos em que ele dizia que era índio, filho de pais 'puro índio', e que não se envergonhava dessa condição. Com essas palavras ecoando nas mentes, os filhos do falecido pajé sugeriram aos outros moradores que deveriam se assumir como indios e buscar a demarcação das suas terras (VAZ, 2010, p. 20).

Nas circunstâncias favoráveis tanto para afirmações identitárias como para a criação de novas Unidades de Conservação no Brasil, dois acontecimentos de grande importância ocorreram simultaneamente no Baixo Tapajós, mobilizando grande número de instituições e entidades. Florêncio Vaz criou o Grupo Consciência Indígena (GCI), em 1997, a partir do Grupo de Reflexão dos Religiosos Negros e Indígenas (GRENI). Ribeirinhos da região mobilizaram-se pela criação da Resex Tapajós-Arapiúns, que se deu em novembro de 1998, relacionando-se, sem se confundir, com o fenômeno das emergências étnicas na região. A criação da Resex envolveu o CNPT/IBAMA, interessado nessa modalidade de Unidade de Conservação, como forma de proteger a floresta, o Sindicato de Trabalhadores Rurais (STR) e o Ministério Público Federal (MPF), entre outras instituições, e logrou retirar da área atividades madeireiras e mineradoras. 
O movimento indígena foi impulsionado inicialmente pelo GCI, e logo após pelo Conselho Indígena dos Rios Tapajós e Arapiúns (CITA), que surgiu em 2000, e promoveu o reconhecimento dos indígenas do Baixo Tapajós pela Coordenação das Organizações Indígenas da Amazônia Brasileira (COIAB). O Conselho Indigenista Missionário (CIMI), conforme relata Vaz (2010), completou a integração do movimento ao ambiente institucional ligado à questão indígena, inclusive a FUNAI, que conduziu o laudo antropológico na Flona Tapajós, objetivando a delimitação de terras indígenas naquela área.

Algumas pessoas em posição de liderança que participaram da luta pela criação da Resex Tapajós-Arapiúns são hoje ativistas da resistência indígena, talvez daí a presença importante do movimento na Resex. O movimento, desde uma missa indígena, ritual que poderia ser interpretado como uma cerimônia de inauguração, realizada em abril de 1999, na comunidade de Takuara (Flona Tapajós), cresceu, incorporando comunidades então tidas como caboclas na Flona Tapajós, na Resex Tapajós-Arapiúns, no Planalto Santareno, na Gleba Nova Olinda e no PAE Lago Grande.

Segundo Edviges Ioris (2005, p. 284), o movimento indígena na Flona Tapajós surgiu como reação à identidade genérica de população tradicional imposta pelo governo, cuja definição era fundamentalmente baseada em critérios ecológicos e não socioculturais. De acordo com a autora, não foi apenas para permanecer em suas terras que as comunidades indígenas se engajaram na luta, mas também para exercer um particular modo de vida que a categoria população tradicional negava. Reclamando antigas referências culturais como um modo de distanciar-se desse genérico e externamente imposto rótulo, os índios Mundurucu das aldeias Takuara, Marituba e Bragança, redirecionaram suas prévias formas de luta pela terra, voltando-se para a FUNAI, em busca de ter seus territórios oficialmente reconhecidos como terras indígenas. Assim, identificando-se como Mundurucus, eles precipitaram uma diferente definição dos espaços territoriais na Flona Tapajós, e daí em toda a região.

Ultrapassada no plano legal, a ideologia expressa pelo "não sou índio porque não sou puro" está, contudo, ainda muito presente no senso comum: num debate em Santarém, um jovem universitário reportou discussão que teve com seu pai, que não se reconhecia indígena porque "não era puro índio". Embora esteja ficando para trás, tem ainda alguma vigência a ideia de que, misturandose com outros, o índio deixa de sê-lo. Agentes da política regional, somando atávicos preconceitos e interesses de classe, reforçam essa visão atrasada, de toda sorte vivamente contestada pela juventude bem informada. Tanto é que, logo após o jovem universitário reproduzir a opinião do seu pai, outro jovem presente 
no debate replicou: "nós somos parentes e isso não é uma questão de DNA. Não é o lado biológico que define. Nós temos uma história comum".

Partindo de outro evento carregado de simbolismo, o I Encontro dos Povos Indígenas do rio Tapajós, que se deu na passagem de 1999 para o ano 2000, na comunidade de Jauarituba, onde cerca de dez comunidades celebraram os 500 anos de resistência indígena, promovendo cantorias, danças e rituais (VAZ, 2010, p. 23), conta-se, hoje, na região (municípios de Santarém, Belterra e Aveiro), 48 aldeias, em que seus moradores - não todos -declaram-se indígenas, identificando-se como Munduruku, Apiaká, Borari, Maytapu, Cara Preta, Tupinambá, Cumaruara, Arapium, Jaraqui, Tapajó, Tupaiu e Arara Vermelha.

Florêncio Vaz, fazendo um balanço do movimento em 1999, informava que dos 40 povoados então abrangidos pelo movimento, em 20 deles o termo aldeia era adotado, onde "os indígenas são a totalidade ou a maioria dos moradores, e os poucos não indígenas não contestam o processo de demarcação das TIs" (VAZ, 2010, p. 38). Por ocasião das atividades levadas a efeito em Santarém, na Semana dos Povos Indígenas, o Conselho Indígena Tapajós-Arapiúns (CITA) preparou uma relação das aldeias indígenas no Baixo Tapajós, que permite uma visão de conjunto (Tabela 1).

Tabela 1: Quadro atual de povos e aldeias indígenas no Baixo Tapajós

\begin{tabular}{|c|c|c|c|}
\hline Aldeias & Povos & Famílias & Habitantes \\
\hline \multicolumn{4}{|c|}{ Região do Arapiuns e Maró } \\
\hline Vila Franca & Arapium & 54 & 250 \\
\hline Cutile & Arapium & 5 & 25 \\
\hline São João Tapiira & Arapium & 15 & 88 \\
\hline Nova Vista & Arapium & 53 & 250 \\
\hline Murici/São Pedro & Arapium & 30 & 152 \\
\hline São Miguel & Arapium & 10 & 68 \\
\hline Ywarete/Bom Futuro & Apiaka & 5 & 28 \\
\hline Lago da Praia & Jaraki & 38 & 187 \\
\hline Arapiranga & Arara Vermelha & 10 & 50 \\
\hline Caruci & Arapium & 27 & 112 \\
\hline Cachoeira do Maró & Arapium & 35 & 238 \\
\hline São José III & Arapium & 20 & 106 \\
\hline Novo Lugar & Borari & 20 & 97 \\
\hline Camará & Arapium & 18 & 123 \\
\hline Braço Grande & Arapium & 12 & 91 \\
\hline Arimum & Arapium & 12 & 88 \\
\hline Garimpo & Tapajó & 20 & 138 \\
\hline Nova Pedreira & Arapium & 15 & 121 \\
\hline Aningalzinho & Tupaiú & 22 & 147 \\
\hline
\end{tabular}




\begin{tabular}{l|l|c|c}
\hline \multicolumn{1}{c|}{ Aldeias } & \multicolumn{1}{|c|}{ Povos } & Famílias & Habitantes \\
\hline Aminá & Tupaiú & 32 & 248 \\
\hline Zaire & Tupaiú & 10 & 78 \\
\hline São Sebastião & Arapium & 8 & 68 \\
\hline Miripixi & Arapium & 9 & 35 \\
\hline \multicolumn{2}{l|}{ Subtotal região do Arapiúns e Maró } & 480 & 2788 \\
\hline
\end{tabular}

Planalto Santareno

\begin{tabular}{l|l|c|c}
\hline Açaizal & Munduruku & 40 & 203 \\
\hline São Francisco da Cavada & Munduruku & 46 & 255 \\
\hline Ipaupixuna & Munduruku & 22 & 141 \\
\hline Lagoa & Munduruku & 10 & 48 \\
\hline São Pedro Curucurui & Borari & 12 & 48 \\
\hline Jacaré & $?$ & 10 & 43 \\
\hline Alter do Chão & $\begin{array}{l}\text { Borari/Arapium/ } \\
\text { Munduruku }\end{array}$ & 168 & 508 \\
\hline \multicolumn{2}{l|}{ Subtotal Planalto Santareno } & 308 & 1246 \\
\hline
\end{tabular}

Região das Aldeias do Rio Tapajós

\begin{tabular}{l|l|c|c}
\hline Jauarituba & Tupinambá & 40 & 198 \\
\hline Santo Amaro & Tupinambá & 26 & 148 \\
\hline Jaca & Tupinambá & 16 & 118 \\
\hline Paraná Pixuna & Tupinambá & 10 & 48 \\
\hline Muratuba & Tupinambá & 15 & 162 \\
\hline Mirixituba & Tupinambá & 15 & 88 \\
\hline Subtotal Aldeias do Rio Tapajós & 122 & 762 \\
\hline Município de Aveiro & 26 & 168 \\
\hline Pinhel & Maytapu & 35 & 186 \\
\hline Escrivão & Cara Preta Munduruku & 61 & 354 \\
\hline Subtotal município de Aveiro & $\mathbf{9 7 1}$ & $\mathbf{5 . 1 5 0}$ \\
\hline
\end{tabular}

Ao explicar o crescimento dos números que quantificam a força do movimento, o Frei Florêncio Vaz, a exemplo de Viveiros de Castro, aponta àquela reversão importante: "Índio era uma identidade transitória, era aquilo que se deixava de ser. Mas índio não é algo que se deixa. Se pensou que era assim, mas hoje não. Alguns que pensavam que eram brancos estão voltando a se identificar como indígenas". O movimento indígena tem ambições: "Até 2000 estávamos com um crescimento fantástico e pensávamos que toda a Resex seria demarcada como terra indígena. Se não tivéssemos todo aquele conflito, aquele baque em 2001”, avalia Florêncio. O movimento cresce, mas enfrenta conflitos internos. O conflito corrente se estabelece com alguns dirigentes do CITA, que estão agora a reivindicar autonomia. "Não queremos mais ser tutelados pela igreja", afirma um membro do CITA, aludindo à condição religiosa de Florêncio e reproduzindo 
um recorrente posicionamento de lideranças leigas criadas na relação com instituições e agentes religiosos.

\section{Ação coletiva para a conquista da Terra Indígena Maró}

A conquista da TI Maró se deu pela possibilidade ou "brecha" criada pelo governo, de as comunidades locais participarem do processo de ordenamento fundiário no conjunto de glebas Mamurú-Arapiuns. Coisa que fizeram inclusive por meio de uma cartografia que as colocou no mapa. Antes disso, contudo, já havia se formado em três delas uma consciência de direitos indígenas. A história da TI Maró é uma narrativa importante no Baixo Tapajós. Ela mostra o êxito de uma ação coletiva em contexto de conflito; uma ação capaz de influenciar o ordenamento territorial na Gleba Nova Olinda I.

Fato decisivo para a tomada de consciência de direitos indígenas foi a visita que a comunidade de Novo Lugar ${ }^{10}$ recebeu, em janeiro de 2002, de uma equipe da Igreja Católica, liderada pela irmã Manoela, do Conselho Indigenista Missionário (CIMI). Essa equipe se reuniu com a comunidade e informou sobre a Constituição Brasileira, sobre o direito que sustentava o movimento indígena ao qual outras comunidades da região estavam aderindo.

Nessa época, uma liderança da comunidade, Odair José, conhecido como Dadá, havia se integrado ao movimento indígena e compunha a coordenação do Conselho Indigenista Missionário (CITA). No seu papel de cacique, Dadán ${ }^{11}$ ajudou a organizar os homens das três comunidades da TI Maró para demarcar a área. "Na verdade o nosso objetivo não era demarcar o mapa, mas abrir os ramais abertos pelos meus bisavôs", afirma o cacique Dadá. Mesmo tendo sido desaconselhados pelo Ministério Público, escreveram uma carta aos órgãos

10 De acordo com relatos dos moradores, a história de Novo Lugar e de algumas comunidades vizinhas tem cerca de 130 anos. Os índios Borari viviam em Alter do Chão, no Atodi, quando foram expulsos pela "grande migração", promovida pelo ciclo da borracha, e assim decidiram subir o rio para encontrar um lugar onde pudessem garantir sua sobrevivência e reprodução social. Inicialmente não se instalaram na beira do rio Maró; entraram mais ao interno e se organizaram em Bejuaçú, em uma das "vidas", como eles denominam as nascentes da terra indígena. Dentro da mata, os indígenas mantiveram vivos os seus rituais, mesmo que os praticando de forma velada, porque sofriam forte discriminação. Garantem que a raiz do índio está na pajelança e que a comunidade sempre praticou os rituais de cura. O grupo, ao longo do tempo, nunca deixou de se organizar, sob a liderança de uma sucessão de caciques.

11 Dadá tornou-se reconhecido por denunciar a exploração ilegal de madeira. Sua atitude lhe rendeu, em 2007, o prêmio José Carlos Castro de Direitos Humanos, da Ordem dos Advogados do Brasil. O cacique tem sido vítima de inúmeras ameaças e atentados e, por isso, recebe proteção policial através do Programa Estadual de Proteção aos Defensores de Direitos Humanos do Estado do Pará. 
competentes informando que começariam a demarcar por conta própria. Uma pequena equipe de comunitários pegou instruções sobre a utilização do GPS na ONG Projeto Saúde e Alegria (PSA) e tomou emprestado um aparelho. Além disso, eles conseguiram a quantia de dois mil reais com a Comissão Pastoral da Terra (CPT), dinheiro que serviu para comprar alimentos e munição para sustentar os homens que fariam a incursão na mata.

As três comunidades, apoiadas por um conjunto de ONGs - CIMI, CITA, PSA, CPT e Grupo de Trabalho Amazônia (GTA) -, demarcaram a TI Maró, elaborando uma cartografia que mostrava os limites da terra indígena. Essa iniciativa afirmou os indígenas como sujeitos políticos e a importância das alianças políticas. Quando o governo instituiu a ALAP, através de uma comissão formada por três órgãos estaduais (IDEFLOR, SEMA e ITERPA), pretendia um processo participativo, de forma que as comunidades indicassem as modalidades de destinação pleiteadas. Esse processo encontrou os indígenas bem preparados.

Para influírem no ordenamento territorial da Gleba Nova Olinda I, as comunidades, apoiadas pelo STTR/Santarém e pela CPT, e com a colaboração do IBAMA e do Projeto Saúde e Alegria, organizaram um seminário para discutir a ALAP. ${ }^{12}$ Nessa oportunidade, 51 comunidades elaboraram um mapa participativo, fazendo valer seus conhecimentos para o diagnóstico e planejamento daquele espaço. Os comunitários apontaram suas áreas de uso e os limites de suas comunidades, baseados na localização de rios e igarapés. No mapa, indicaram as modalidades de titulação mais convenientes a cada comunidade. ${ }^{13}$ Com essa iniciativa, as comunidades se respaldaram frente ao governo, para o processo de destinação territorial nas glebas Mamurú-Arapiuns.

Os mapas participativos permitem a documentação da realidade pelos grupos sociais que sempre passaram desapercebidos pelos mapas e documentos oficiais, tornando visíveis os conflitos e reivindicações. Configuram-se como uma estratégia de ação coletiva garantindo o direito a terra e a conservação dos recursos naturais utilizados direta ou indiretamente (STTR/SANTARÉM; CPT 2008, p.9).

Resultado importante desse processo foi a produção de uma representação cartográfica que, além das demandas comunitárias relativas aos assentamentos,

12 Seminário de Elaboração Participativa de Mosaico de Uso da Terra na ALAP Nova Olinda/ Mamurú, no Oeste do Pará (13-14/11/2008).

13 O mapa alicerçou o "Plano Participativo de Mosaico de Uso da Terra nas Glebas: Nova Olinda, Nova Olinda II e III, Cumurucuri e Mamurú no Oeste do Pará” (STTR/SANTARÉM; CPT, 2008) e indicou cinco Projetos Estaduais de Assentamento Extrativistas (PEAX): Curumucuri, Mamurú, Aruã, Vista Alegre e Mariazinha; três Projetos Estaduais de Assentamento Sustentável (PEAS): Aruã-Maró, Fé em Deus e Repartimento; o Parque Estadual do Mamurú; a Floresta Estadual do Alto Aruã (Unidade de Conservação de Uso Sustentável); e a Terra Indígena Maró. 
acatou uma reserva de área para a Terra Indígena Maró. Os autodenominados indígenas Borari e Arapium, das comunidades de Cachoeira do Maró, Novo Lugar e São José III não aceitavam ser enquadrados nos projetos de assentamento propostos pelo Estado, que para eles não atendia ao objetivo de garantir território. A territorialidade proposta pelo Estado colidia com a territorialidade que eles queriam ter.

Em cenário de disputas territoriais, o fato de os indígenas possuírem uma representação cartográfica de si mesmos mostrou-se fundamental para encaminhar a garantia de seus direitos. Diferentemente das comunidades vizinhas, que reivindicavam lotes de terra, as aldeias de Novo Lugar, São José III e Cachoeira do Maró lutavam pela terra como base física para um modo de vida. A terra, para eles, tem um significado existencial. A conquista da TI Maró se relaciona diretamente à sobrevivência do grupo. A ligação dos indígenas com o território significa a própria existência:

Pertencemos a um território, não o possuímos, guardamo-lo, habitamo-lo, impregnamo-nos dele. Além disso, os viventes não são os únicos a ocupar o território, a presença dos mortos marca-o mais do que nunca com o signo sagrado. Enfim, o território não diz respeito apenas à função ou ao ter, mas ao ser. Esquecer este princípio espiritual e não material é se sujeitar a não compreender a violência trágica de muitas lutas e conflitos que afetam o mundo de hoje: perder seu território é desaparecer (BONNEMAISON; CAMBRÈZY, apud HAESBAERT, 2006, p.51).

Perder a terra é enterrar a história, os lugares sagrados, a vida como povo. E os inimigos estavam ali desmatando, ocupando território e ameaçando seu modo de vida. Cansados de ver subir pelos rios balsas carregadas de madeira, e de denunciar o fato às autoridades sem qualquer resultado, sujeitos políticos, tomando a iniciativa de suas ações, resolveram agir por conta própria. No dia 10 de novembro de 2009, queimaram duas balsas carregadas de madeira, supostamente ilegal. A carga foi avaliada em $\mathrm{R} \$ 5$ milhões de reais e queimou por três noites. O fato foi um divisor de águas e marcou a história do Baixo Tapajós.

A tensão aumentou após o incêndio. Madeireiros contrariados passaram a incentivar o ódio na população local. Alguns jornalistas da imprensa santarena veicularam matérias afirmando que os indígenas não são verdadeiros, apontandoos como responsáveis pelo atraso econômico ao inviabilizar o uso produtivo das terras regionais. Por um lado, a reação ao movimento indígena se fez mais forte, mas, por outro, o evento da queima das balsas despertou a atenção do Ministério Público Federal em Santarém, que iniciou uma Ação Civil Pública para acompanhar o processo de demarcação. 
O processo administrativo de demarcação da Terra Indígena Maró havia sido iniciado em 2004 pela FUNAI, com a realização dos estudos antropológicos. Porém, a FUNAI tardava em publicar o Relatório de Identificação e Delimitação. Os indígenas ansiavam por essa publicação, pois era este o documento que definiria o reconhecimento formal e o tamanho da área da TI. Depois de uma longa espera, em 8 de junho de 2011, a Justiça Federal em Santarém determinou à FUNAI que publicasse em trinta dias o relatório de identificação e delimitação da TI Maró, sob pena de multa diária, no caso de descumprimento. Finalmente, em 7 de outubro de 2011, o Despacho no 107, “considerando a Decisão do Juízo Federal da Seção Judiciária do Pará, Subseção de Santarém", reconhece "os estudos de identificação da Terra Indígena Maró de ocupação dos grupos indígenas Borari e Arapium”.

O relatório, assinado pela antropóloga Georgia da Silva, contém passagem relevante para a compreensão do conflito enfrentado pelos indígenas, que já não podiam caçar e pescar em seus locais tradicionais, já que cercas e portões proibiam a entrada de "estranhos":

É importante destacar que cientes do processo de usurpação de sua área de ocupação permanente, os Barari e Arapium em 2005 realizaram a primeira autodemarcação de seus limites territoriais em projeto conjunto entre o Conselho Indígena Tapajós-Arapiuns e Programa Saúde e Alegria. Em 2007 foi realizado o georeferenciamento dos pontos identificados. Os limites apresentados no mapa de autodemarcação, em alguns momentos, contrastam com as narrativas proferidas pelos indígenas quando da entrada na mata e da utilização dos recursos naturais lá existentes. Alguns igarapés (especialmente suas cabeceiras), como o do Cachimbo e do Arraia, são tidos pelos indígenas como importantes, mas não aparecem nos limites geográficos. Lendo o mapa de autodemarcação é possível perceber que todos os pontos de conflito e nos quais os indígenas se sentem pressionados em seu território, não são contemplados, numa nítida reação de medo as ameaças sofridas (FUNAI, 2011).

O relatório chama a atenção também para a ação coletiva com que os indígenas se legitimaram para a conquista do território, valorizando o processo político, e dentro dele a autodemarcação:

A autodemarcação reforçou um sentimento de pertença a um espaço comum, a partir de narrativas dos mais velhos sobre o uso do espaço e dos recursos há mais de uma década. A autodemarcação, como campo de experiência, também legitima o processo de reivindicação política territorial [...]. Esses sinais apontam para a construção coletiva do território [...]. Como o mapa de autodemarcação se constitui como uma referência política, simbólica e principalmente de reconhecimento dos espaços de significação territorial dos indígenas, este foi usado como suporte para pensar a TI Maró, pois imprime os principais vértices de reconhecimento territorial dos Barari e Arapium (FUNAI, 2011). 


\section{O indígena é o caboclo politicamente posicionado}

Estes "trabalham da mão para a boca, tal é a sua penúria". Com essa frase, Darcy Ribeiro (2006, p. 305) definiu a condição do caboclo na Amazônia. "Em nenhuma outra região brasileira a população enfrenta tão duras condições de miserabilidade quanto os núcleos caboclos dispersos pela floresta" (RIBEIRO, 2006, p. 280), escreveu o autor em 1995. Contudo, visitando as comunidades do Tapajós e Arapiuns não se vê miséria realmente. A aposentadoria rural, o programa bolsa família, as atividades de subsistência, a caça, a pesca, o açaí e a venda da farinha de mandioca no mercado, alguns artesanatos também comercializados em Santarém, tudo somado, permite aos comunitários viverem modestamente, fora do quadro miserável que o autor provavelmente viu em outros lugares da Amazônia cabocla. De uns tempos para cá, os brasileiros mais desfavorecidos tiveram um pouco melhorada sua condição de vida. Mas é verdade que a tiveram só um pouco. Os caboclos continuam pobres, a opulência da natureza contrastando com sua existência simples. Mas o problema não é esse realmente. Como diz Deborah de Magalhães Lima (1999, p. 13), "pobreza também é um conceito cultural. O caboclo não é só pobre em relação a padrões de vida urbanos ou internacionais, mas também em relação a uma expectativa elevada para a performance econômica e social deste neobrasileiro na Amazônia" (LIMA, 1999, p. 13).

O problema não está na simplicidade da sua condição material de vida, mas no sentido negativo que o termo caboclo implica nominação atribuída por outros para classificar negativamente esse típico habitante da Amazônia, desprovido, enquanto caboclo, de uma identidade coletiva autoafirmada, depreciado, imobilizado e feito invisível justamente por essa falta de identidade. "A permanência do nome restringe as possibilidades de emancipação" (LIMA, 1999, p. 28). Assim, no Baixo Tapajós, para enfrentar a exploração econômica da natureza que ameaça seu modo de vida, e para se relacionar em melhores condições políticas com o Estado, o caboclo se posiciona como indígena, definindo uma marcante identidade social.

É por isso que a emergência de identidades indígenas em comunidades caboclas é um estimulante fenômeno político. No quadro de uma "sociedade de história lenta”, conforme a definição de José de Souza Martins (1999), onde se vê "no contemporâneo a presença viva e ativa de estruturas fundamentais do passado" (MARTINS, 1999, p. 14), a falta de identidade e a violência continuam a expulsar os caboclos da terra, agora em nome do desenvolvimento sustentável, termo duvidoso que abriga estratégias governamentais e interesses empresariais. 
Muitos desses mestiços, mais indígenas que brancos, oriundos de áreas de onde o capital os expulsou, continuam a descer os rios para viver esqualidamente nas baixadas não saneadas de Belém, Manaus, Santarém e outros centros urbanos da região, onde continuam a sofrer com a classificação negativa que o termo caboclo implica.

Aqueles que resistiram nas suas posses contra o avanço do desenvolvimento, fizeram-no assumindo novas identidades sociais, como Povos da Floresta, por exemplo. Essa resistência, onde desponta a luta de Chico Mendes e do Conselho Nacional de Seringueiros foi decisiva para a conquista da presença humana em áreas de conservação ambiental definidas pelo SNUC, entre as quais se situam as Reservas Extrativistas e as Florestas Nacionais. O consentimento conquistado se fez, contudo, sujeitando os caboclos à condição de "mera extensão dos recursos naturais” (LEROY, 2010, p. 95 apud ALMEIDA, 2007), sob o rótulo de populações tradicionais - ou se fez planejando torná-los mão de obra barata para atividades econômicas.

No caso da Flona Tapajós, Edviges Ioris (2005) observa que as populações nativas não deixaram de ser consideradas pelo Estado. Contudo, essa consideração das agências estatais, depois de permitida sua permanência na área, colocava-as não como beneficiárias do projeto da Flona, mas como objeto de uma manipulação, para servir aos interesses da economia florestal. Em perspectiva histórica, a autora observa que essa falta de apreço para com as populações nativas não representou qualquer novidade, podendo-se rastrear o mesmo tratamento vil desde os tempos coloniais. Ou seja, desde sempre, os projetos oficiais, no afã de produzirem desenvolvimento, esforçam-se para destituir as populações nativas das suas identidades e confiscar seus territórios, a fim de tirar vantagem delas como força de trabalho. A resistência indígena se opõe a essa alienação da autonomia, que se pode verificar, por exemplo, em comunidades dos rios Aruã e Maró cooptadas por empresas madeireiras.

Popularmente, o termo caboclo não é usado para autoidentificação, dado que carrega um significado depreciativo. ${ }^{14}$ Contra essa depreciação humana e essa existência subalterna em projetos alheios, a afirmação de uma altiva identidade indígena representa um acontecimento importante para essas populações sem

14 For example, urban people were inclined to identify rural people as caboclo, while people from big cities also identified the people from smaller towns as caboclo. In the rural areas, class differentiation could also be a criterion to attribute the category of caboclo (the higher class attributes caboclo to the lower class). With a strong pejorative connotation, the term usually was associated with the adjectives rural, indigenous, rustic, illiterate, and uncivilized, in opposition to urban, white, literate, and civilized, a reason why people tended to reject being identified as caboclos, as was found in the Flona Tapajós (IORIS, 2005, p. 2). 
identidade específica, assim como representa um fato social importante no contexto regional. Um fato que retoma a história das nações indígenas que povoavam o Baixo Tapajós em 1671, no ponto de inflexão marcado pela chegada do missionário jesuíta João Felipe Bettendorff na foz do rio para fundar missões e aldeamentos. O descimento dos indígenas para as aldeias rompeu etnias, fez surgir o termo pejorativo caboclo, derivado do tupi caa-boc - "o que vem da floresta" (LIMA, 1999, apud COSTA PEREIRA, 1975) - mas não apagou a cultura indígena que continua resistindo até hoje:

Na Missão dos Arapiuns surgiu, em seguida, um jeito de viver bem peculiar, no qual elementos das culturas indígenas (alimentos, remédios, danças, apego aos pajés) e também na cultura ibérica (procissões, cantos, devoção aos santos) se justapuseram. Como os jesuítas não exerceram - apesar de um regulamento muito rígido - um controle total sobre a população aldeada, a matriz desta nova cultura continuou sendo indígena (ARENZ, 2011).

O indígena, subtraído da sua cultura, posto por outros sem identidade e história, resistiu na sua essência. Esse indígena destribalizado e escravizado, submetido a uma homogeneização deculturativa, cumpriu uma vez papel importante na revolta da Cabanagem - como tapuio ${ }^{15}$, termo usado como sinônimo de caboclo e de cabano - insurgindo-se contra a ordem repressiva. Hostil à ordem dominante, como hoje, de certa maneira, volta a ser, açodando, agora como antes, o ódio das elites locais. ${ }^{16}$

A representação ideológica do caboclo, essa generalizada designação para os descendentes dos povos indígenas submetidos a misturas raciais, e a acomodada aceitação dessa classificação imposta, têm servido para integrar a população amazônica ao desenvolvimento, que demanda terra e mão de obra. Tem sido assim desde os tempos coloniais até os atuais avanços da fronteira econômica, que requer ordenamentos territoriais e a reserva de áreas para a exploração madeireira, tida como a vocação econômica do Oeste do Pará.

15 Na Amazônia, caboclo foi inicialmente usado como sinônimo de tapuio, termo genérico de desprezo que os povos indígenas usavam quando se referiam a indivíduos de outros grupos (LIMA, 1999, p. 9).

16 Expulsos em 1759 pelo Marquês de Pombal, os padres foram substituídos por diretores, isto é, funcionários públicos, e as Missões transformadas em Vilas. A Missão dos Arapiuns tornou-se Vila Franca. Mas a corrupção e os maus-tratos dos diretores causaram uma onda de fugas. Os índios se refugiaram rio acima e fundaram pequenas comunidades rurais. Para desacreditá-los, a população branca passou a chamá-los de ‘tapuias', isto é, 'índios bravos', por terem fugido da ‘civilização’. Anos mais tarde, a Cabanagem (1835-1840) revelou o abismo que existia entre as elites da região e as populações nativas. As lutas e matanças que aconteceram, afastaram ainda mais estes dois grupos. Até se deu outro nome pejorativo aos moradores do interior. Eles foram chamados de 'caboclos', que significa 'aqueles que são do mato” (ARENZ, 2011).

Novos Cadernos NAEA •v. 15 n. 2 • p. 279-313・dez. 2012 
No entanto, contra as expectativas, o movimento indígena se fez presente na Gleba Nova Olinda, seguindo o que ocorreu nas comunidades de Takuara, Marituba e Bragança, situadas na Flona Tapajós. A retomada da identidade indígena em outras áreas do Baixo Tapajós, como o PAE Lago Grande, é possível, mas cresce a reação a essa etnogênese. E seria um exagero dizer que o movimento indígena coloca um grande obstáculo à exploração econômica nessa fronteira; e ainda mais - supor que o movimento abre possibilidades insurrecionais nos moldes de uma Cabanagem. Que o movimento indígena incomoda interesses localizados - é fato: o ITERPA contesta a Terra Indígena Maró, segundo esse instituto, criada "via processos espúrios", contrariando "elevados interesses do Estado do Pará". Se a dimensão do movimento indígena não é assim tão grande, pelo menos ele permite às populações nativas, como sujeitos coletivos, um confronto com o Estado em melhores condições políticas, como dizia Bartolomé (2006). Como indígenas, elas reivindicam saúde, educação e território, direitos que aos caboclos são ainda mais limitados. Além disso, eles se orgulham de governar seus próprios objetivos. É nessa medida que o posicionamento político do caboclo assenta uma relevante questão.

\section{Uma história aberta}

O Baixo Tapajós celebra 14 anos de movimento indígena. Na linda comunidade de Muratuba, agora aldeia Munduruku, que conta com um telecentro de inclusão digital, moradores compartilham um ritual com uma turma de estudantes universitários. Toalha vermelha sobre a terra, cupuaçu, arroz e cuias sobre ela. Pés no chão. O tarubá é servido a todos e na roda o xibé também circula. Cânticos evocam Tupã. Água, terra e povo: o cacique invoca os valores fundamentais. Frei Florêncio lembra a Cabanagem, aludida na toalha vermelha. Lembra também os 15 anos de Eldorado de Carajás, "lutas dos insurgentes contra os poderosos de ontem e de hoje". Eles discutem as ameaças postas pelas hidrelétricas projetadas no rio Tapajós. "É preciso acordar, é preciso a gente se unir". Indiazinhas adornadas se apresentam em números de dança. A indianidade está patente nos índios e a aldeia é um lugar de convivência entre parentes. A cerimônia continua no barracão aberto e coberto de palha, onde funciona a escola indígena. O ensino médio chegou à aldeia e alguns já falam o nheengatu. A viagem de volta não é um retorno nostálgico ao passado (OLIVEIRA, 1999) - é um movimento político.

Os militantes contestam a história e pregam a resistência. A despeito de séculos de ações realizadas para reduzir, eles - os indígenas - ressignificaram 
a palavra índio e o próprio conceito. O que é ser indígena hoje? Essa é uma pergunta que sempre se faz, e as respostas remetem à história, às raízes, à cultura diferente, ao pertencimento, à luta por direitos: "Ser indígena é estar aqui fazendo história". "É ser alguém com uma cultura diferente, com uma história de vida". "Ser indígena é acessar direitos, é lutar para afirmar esses direitos". "Ser indígena é pertencer a um povo, é ter orgulho da nossa raiz, da nossa história de resistência". "Ser indígena é defender o que é nosso". "Ser indígena é ser nativo". Os estudantes indígenas na Universidade Federal do Oeste do Pará discutem e se formam como novas lideranças do movimento.

A evidência da tradição indígena nas feições e nas condições ambientais dos habitantes ribeirinhos confere peculiaridade e distingue a chamada emergência étnica no Baixo Tapajós do processo precursor ocorrido no Nordeste, onde esses sinais externos não são tão evidentes (OLIVEIRA, 1999). A tradição indígena se manteve viva nas comunidades caboclas e foi capaz de influenciar, com muitos traços típicos, a cultura regional. Aqui, o poder de atração da sociedade nacional foi mais que compensado pela capacidade da cultura indígena permear o padrão popular da sociedade regional. Assim, a emergência étnica no baixo Tapajós se situa na interpretação de Miguel Bartolomé, para quem identificações étnicas como essas “não se 'inventam', mas se atualizam” (BARTOLOMÉ, 2006, p. 57). Embora essa atualização não reproduza o arquétipo indígena de antes da colonização, "recupera-se um passado próprio, ou assumido como próprio, a fim de reconstruir um pertencimento comunitário que permita um acesso mais digno ao presente" (BARTOLOMÉ, 2006, p. 57).

A cultura nativa, originada pela transposição da crença indígena à manifestação religiosa então possível nos aldeamentos catequéticos, é continuada hoje nas festas de santos. Toda a simbologia que caracteriza o cristianismo indígena, mas também a prática do trabalho conjunto no puxirum, as retribuições do putáua, o uso do pilão, do fogão a lenha, a prática de receber os visitantes na cozinha, a cobertura de palha nos "puxados" feitos atrás das casas, ainda que mal construídas em alvenaria pelo INCRA, todo esse conteúdo histórico-cultural significa que não se precisa inventar ali uma tradição, visto que a cultura indígena já se encontra posta. ${ }^{17}$ Não é, pois, o caso de imputar aqui uma tradição inventada, na acepção dada por Hobsbawm, e tampouco de depreciar o fenômeno como

17 O catolicismo entremeado de crenças indígenas, as manifestações do sobrenatural nos encantados, a relevância da figura do curador nas comunidades, onde se conjuga a palavra do padre (ou do médico) com a prática da pajelança. Os procedimentos rituais do pajé: "banhos, chás, defumações, remédios da terra ou do mato (ervas, raízes, folhas etc., sob várias formas de preparo)" (MAUÉS, 1995, p. 186). Tudo isso são indicadores de uma cultura que sempre esteve ali, nas mesmas terras onde os antepassados dos atuais habitantes viveram há centenas de anos. 
uma invenção de caboclos, conforme o senso comum local, alimentado pelo preconceito de agentes institucionais.

$\mathrm{Na}$ imagem construída por uma indígena, "o movimento cresce como uma cheia grande". Mas esse crescimento não se dá sem polêmicas e divisões dentro das comunidades. Uma interrogação intrigante que algumas pessoas colocam é se essa legítima recriação da tradição indígena, essa "maximização da alteridade", na expressão de José Maurício Arruti (1997, p. 19), não se faria em detrimento do caboclo, achatando ainda mais sua condição existencial e sua possibilidade de atuar como sujeito político.

Alguns se perguntam se a construção dessa identidade positiva de índios renascidos na história, não iria ainda mais depreciar a já complexada identidade do caboclo, esse descendente das populações aldeadas, subalternamente assimilado e integrado. Como se daria a solidariedade entre iguais no trato com a natureza e no modo de vida, diferenciados pelo culto da tradição indígena e pela "nomeação", eventualmente reconhecida pela autoridade competente? (ARRUTI, 1997, p. 23) Como se dariam as relações de vizinhança entre as agora renomeadas aldeias indígenas, plenas de visibilidade, e as opacas comunidades caboclas? Restaria ao caboclo algum espaço como sujeito político?

Conversando com um senhor nascido no Lago Grande, área vizinha à Resex Tapajós-Arapiúns, ouvi a seguinte consideração: “sou um nativo, me considero um caboclo e acho um exagero querer que todo mundo vire índio. Acho que o caboclo tem também que trabalhar sua identidade". Cumpre informar que o interlocutor era um informado e bem sucedido cidadão, que manifestava orgulho de sua naturalidade local. Ou seja, sua condição de vida não correspondia a do caboclo de fato - este vivente das beiras, despojado de cidadania, assim como de identidade. O problema é que dificilmente os verdadeiros caboclos se identificam como caboclos. Normalmente, o termo é usado por outros para desclassificar pessoas vistas como inferiores. Eles são identificados negativamente pelo que não são - não são índios e não são civilizados. A identidade do caboclo é negativa; é algo como uma não identidade.

Em cerca da metade das 48 comunidades que se assumem indígenas na região, a identidade indígena não é consensual. Isto estabelece um litígio complexo, até mesmo pela sobreposição de diferentes possibilidades de usos da natureza, não em virtude de diferenças de modos de vida entre o caboclo recalcitrante e o indígena assumido, mas em função das diferentes institucionalidades que regem o mesmo espaço: por um lado, a FUNAI; por outro, o ICMBio, o IBAMA ou o INCRA. "Imagine" - continua o cidadão nativo do Lago Grande - "se uma 
comunidade, mas não toda ela, decide se tornar indígena. Nesse caso, os caboclos teriam de sair?"

O movimento se depara com o desafio de superar impasses para continuar sua expansão, que passa pelo reconhecimento institucional das terras indígenas, mas também por alguma forma de aliança com os outros moradores não indígenas. E quais seriam as alternativas para um movimento que propõe recuperar tradições para afirmar benefícios coletivos? Não se trata somente de direitos materiais, territoriais, inclusive. Também está em jogo a valorização do pertencimento a uma coletividade que, conforme lembra Bartolomé (2006, p. 56), é "carregado de conteúdos afetivos". Até que ponto essa "maximização da alteridade" (BARTOLOMÉ, 2006, p. 56) permite solidariedades entre indígenas e caboclos? A ideologia da identidade étnica pode se articular com o posicionamento de camponeses organizados como classe social - onde se incluiriam os caboclos renomeados - em luta por direitos de cidadania? Índios e camponeses podem, juntos, se não a utopia de uma nova cabanagem, aspirar por saúde, educação e território, unindo movimento étnico e movimento de classe por uma sociedade nova?

\section{REFERÊNCIAS}

ALMEIDA, A. W. B. de. Direitos territoriais e étnicos. As estratégias dos agronegócios na Amazônia. In: ZHOURI, Andrea; LASCHEFSKI, K. (Org.). Desenvolvimento e conflitos ambientais. Belo Horizonte: EDUFMG, 2010.

ARENZ, K. H. São e salvo: a pajelança da população ribeirinha do Baixo Amazonas como desafio para a evangelização. Quito: Abya-Yala, 2003.

Os Primórdios. Prazer em Conhecer. Terra Indígena do Maró. Santarém: CEAPS/Projeto Saúde e Alegria, 2011.

ARRUTI, J. M. A. A emergência dos “remanescentes": notas para o diálogo entre indígenas e quilombolas. Mana, v. 3, n. 2, p. 7-38, 1997.

BARTH, F. Ethnic Groups and Boundaries. Bergen-Oslo: Universitets Forlaget, 1969.

BARTOLOMÉ, M. A. As etnogêneses: velhos atores e novos papéis no cenário cultural e político. Mana, v. 12, n. 1, p. 39-68, 2006. 
CÁRDENAS, O. B. Constructing indigenous ethnicities and claiming land rights in the lower Tapajós and Arapiuns region, Brazilian Amazon. 2008. Dissertation (Doctor of Philosophy) - University of Florida, 2008.

CARDOSO DE OLIVEIRA, R. Identidade, etnia e estrutura social. São Paulo: Livraria Pioneira, 1976.

CASTRO, E. Dinâmica socioeconômica e desmatamento na Amazônia. Novos Cadernos NAEA, Belém, v. 8, n. 2, dez. 2005.

CASTRO, E. V. de. No Brasil, todo mundo é índio, exceto quem não é. Povos Indígenas no Brasil 2001/2005. São Paulo: Instituto Socioambiental, 2006.

FISHER, W. Conflitos territoriais e disputas cartográficas: tramas sociopolíticas no ordenamento territorial do Oeste do Pará. In: ACSERALD, H. Cartografia social e dinâmicas territoriais: marcos para o debate. Rio de Janeiro: IPPUR/ UFRJ, 2010.

FONTES, M. Após incêndio, procurador do MPF diz que conflito em Santarém não terminou. In: Globo Amazônia, 12/11/2009. Disponível em: <www. globoamazonia.com.>. Acesso em: 20 dez. 2011.

FUNAI-FUNDAÇÃO NACIONAL DO ÍNDIO. Relatório Circunstanciado de Identificação e Delimitação da Terra Índigena Cobra Grande (Santarém/PA). Brasília, DF: Ministério da Justiça, 2009.

FUNAI-FUNDAÇÃO NACIONAL DO ÍNDIO. Resumo do Relatório Circunstanciado de Identificação e Delimitação da Terra Indígena Maró/ PA. Despacho no 107, de 7 de outubro de 2011. Brasília, DF: Ministério da Justiça, 2011.

GIDDENS, A. A constituição da sociedade. São Paulo: Martins Fontes, 1989.

PARÁ. GOVERNO DO ESTADO. Ofício ao Presidente da Fundação Nacional do Índio - FUNAI, assinado por Carlos Lamarão Corrêa, em Belém, 4 de janeiro de 2012. Belém: Instituto de Terras do Pará, 2012.

HAESBAERT, R. O Mito da desterritorialização. Rio de janeiro: Bertrand Brasil, 2007.

HOBSBAWM, E. Introdução: a invenção das tradições. In: HOBSBAWM, E.; RANGER, T. A invenção das tradições. Rio de Janeiro: Paz e Terra, 1984. 
IDEFLOR. Instituto de Desenvolvimento Florestal do Pará. Projeto de Desenvolvimento Comunitário: fortalecimento da economia agroflorestal e extrativista das comunidades na Gleba Nova Olinda I". Belém, julho 2009. Disponível em http://www.ideflor.pa.gov.br/files/u3/Nova_Olinda_ideflor1. pdf. Acessado em 5 mar. 2011.

IORIS, E. M. A Forest of disputes: struggles over spaces, resources, and social identities in Amazonia. 2005. Dissertation (Doctor of Philosophy) - University of Florida, 2005.

ITERPA. Portaria $\mathbf{n}^{\mathbf{0}}$ 0798. Criação as glebas Nova Olinda e Mamuru. Belém, 22 de dezembro de 1999.

JORNAL O IMPACTO. n. 837. 10 de junho de 2011. Disponível em: <www. calameo.com/books/000553111ab916fcaq59e>. Acesso em: 15 jan. 2012.

LENA, P.; OLIVEIRA, A. E. de. Amazônia - a fronteira agrícola 20 anos depois. Belém: Museu Paraense Emílio Goeldi, 1991.

LEROY, J. P. Amazônia. Território do capital e territórios dos povos. In: ZHOURI, A.; LASCHEFSKI, K. (Org.). Desenvolvimento e conflitos ambientais. Belo Horizonte: EDUFMG, 2010.

LIMA, D. de M. A construção histórica do termo caboclo. Sobre estruturas e representações sociais no meio rural amazônico. Novos Cadernos NAEA, v. 2, n. 2, dez. 1999.

LOUREIRO, V. R. Amazônia - Estado, Homem, Natureza. Belém: Cejup, 2004.

MARTINS, J. de S. O poder do atraso: ensaios de sociologia da história lenta. 2. ed. São Paulo: Hucitec, 1999.

MAUÉS, R. H. Padres, Pajés, Santos e Festas: Catolicismo Popular e Controle Eclesiástico. Um estudo antropológico numa área do interior da Amazônia. Belém: Cejup, 1995.

MILANEZ, F. Medo e Tensão no Oeste. Revista Rolling Stones, out., 2010. Disponível em http://terradedireitos.org.br/biblioteca/gleba-novaolinda-santarem-pa-\%E2\% 80\%93-\%E2\%80\%9 Cmedo-e-tensao-nooeste $\%$ E2\%80\%9D/. Acessado em: 5 mar. 2011.

MOREIRA NETO, C. de A. Índios da Amazônia, de Maioria a Minoria (1750-1850). Petrópolis: Vozes, 1988. 
ODILLA, F. Aval para Belo Monte teve oposição na Funai. Folha de S. Paulo, 28 jan. 2011. Disponível em: http://www.ihu.unisinos.br/noticias/40294-avalparabelo-monte-teve-oposicao-na-funai. Acesso em: 5 mar. 2011.

O'DWYER, E. C. Os quilombos do Trombetas e do Erepecuru-Cuminá. In: O'DWYER, E. C. (Org.). Quilombos: edentidade étnica e territorialidade. Rio de Janeiro: FGV, 2002.

OLIVEIRA, J. P. de. Uma etnologia dos "índios misturados": situação colonial, territorialização e fluxos culturais. In: OLIVEIRA, J. P. de (Org.). A viagem de volta: etnicidade, política e reelaboração cultural no Nordeste indígena. Rio de Janeiro: Contra Capa, 1999.

PEIXOTO, R. Indígenas resistentes se movimentam por identidade e território no Baixo Tapajós. In: CONFERÊNCIA DA SALSA, 7. 2011. Belém. Anais... Belém, 2011. Mimeografado.

RIBEIRO, D. O povo brasileiro: a formação e o sentido do Brasil. São Paulo: Companhia das Letras, 2006.

SARAIVA, M. P. Identidade Multifacetada: a reconstrução do "ser indígena" entre os Juruna do médio Xingu. Belém: UFPA, NAEA, 2007.

STTR-SINDICATO DOS TRABALHADORES RURAIS DE SANTARÉM; CPT-COMISSÃO PASTORAL DA TERRA. Plano Participativo de Mosaico de Uso da Terra nas Glebas Nova Olinda, Nova Olinda II, III, Cumurucuri e Mamuru, no Oeste do Pará. Santarém: STTR; CPT, 2008.

VAINER, C. Regionalismo e projeto nacional: uma reflexão sobre regionalismos velhos e novos. Cadernos IPPUR, Rio de Janeiro, v. 7, n. 2, set. 1993.

VAZ, F. de A. A emergência étnica de povos indígenas no Baixo Rio Tapajós, Amazônia. Plano de Tese. Salvador: Universidade Federal da Bahia, Programa de Pós-Graduação em Ciências Sociais da Faculdade de Filosofia e Ciências Humanas, 2010.

Identidade indígena no Brasil hoje. Santarém: UFOPA, 2010. (Festival de Direitos, 25-29/10/2010).

WEBER, M. Conceitos básicos de Sociologia. São Paulo: Centauro, 2002. 


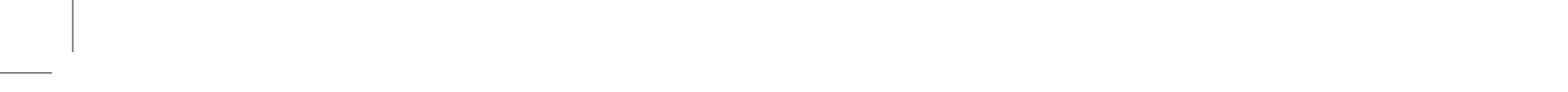

